these being on neuroleptics. McClelland et al (1974), showed that approximately all but $8 \%$ of this type of medication could be discontined.

These findings point to where there are possible savings in the drug budget, and definite savings in the nursing time involved in long and frequent drug administration rounds. Knowledge of individual patients is not necessary for this survey to show the need for rational pharmacotherapy.

\title{
References
}

AyD, F. J. (1973) Rational pharmacotherapy: Once-a-day drug dosage. Diseases of the Nervous System, 34, 371-8.

McClelland, H. A., Blessed, G., Bhate, S., Ali, N. \& Clarke, P. A. (1974) The abrupt withorawal of antiparkinsonian drugs in schizophrenic patients. British Journal of Psychiatry, 124, 151-159.

The Maudsley Hospital,

NeIL L. Holden

Denmark Hill,

London SE5 8AZ.

SIR,

\section{INJURIES IN A PSYCHIATRIC HOSPITAL}

The relationship between individual psychopathology and institutional life in chronic psychiatric inpatients has been a matter of much debate, as the behaviour may be regarded as a result of mental illness or as being promoted by the disturbed environment.

As an indicator of pathological aggressivity I considered injuries in the records of 130 chronic psychotics between January 1980 and May 1982. The patients were 33 females and 97 males with an average age of 59 years and periods of hospitalization from 15 to 30 years. There were 53 schizophrenics, 50 oligophrenics, 14 demented, 5 epileptics, 4 manicdepressives, 2 hypochondriacs, 1 general paresis and 1 morbus Fahr patients.

An injury, whether accidental, self produced or inflicted by another person, always constitutes an emerging signal of an altered psychological equilibrium. The following, according to the results of my research, are the main factors facilitating or inhibiting hetero or auto directed aggressivity:

\section{Facilitating factors}

1. Crowding of the inpatients

2. Seriousness of psychopathology of the patients

3. Degree of restraint put upon the patients
Inhibiting factors

1. Functioning and cooperation of the nursing staff

2. Improvement of the patients' mental state

3. Increase of psychopharmacological therapy
The chronicity of the institution, a typical psychiatric hospital, is shown by the fact that, during the period of time taken into consideration, factor no. 2 remained constant. A trial of psychiatric reform brought about a general decrease of factors 1 and 3 .

As a result there was an increase of patients' injuries: the rate of injuries per month changed from 5.0 in 1980 , to 5.9 in 1981 and 5.8 in 1982. The $\chi_{c}^{2}$, however, in the years 1980 and 1981 , both for total patients d.f. $=1)$ and for male patients $($ d.f. $=1)$ is not significant (total patients $\chi_{c}^{2}=2.35$; male patients $\left.\chi_{c}^{2}=3.18\right)$.

Since the psychiatric hospital was at the time overrun by many and conflicting trends in the light of the psychiatric reform, the present data may partially support Sacerdoti's view (1971) that in an asylum (pathological) conflicts of the nursing staff are projected on to the patients, provoking an increase of aggressivity. Similarly it has indeed been demonstrated that the length of manic episodes correlated with the attitude of the nursing staff (Rizzoli, 1975). The salient factor seems to have been the diminished cooperation and friendliness of the nurses, which can be ascribed not only to the general worsening of medical assistance in Italy, but also to some conservative attitudes towards any serious effort of institutional reform. From this point of view the preventive measures suggested by Hawton and Leopoldt (1978) may represent a sort of Verneinung of the pathology of institutions.

Ospedale Psichiatrico

Antonio A. Rizzoli

Marocco, Via Marocchesa 18

Venezia, Italy

\section{References}

Hawton, K. \& Leopoldt, H. (1978) Accidents in a psychiatric Hospital. British Journal of Psychiatry, 133, $224-7$.

Rizzoli, A. A. (1975) Gli stati di eccitamento e le terapie $i$ stituzionali, Neopsichiatria, 41, 1, 63-71.

SACERDOTI, G. (1971) Fantasmi, miti e difese nell'assistenza psichiatrica Rivista di Psicanalisi, XVII, 83-110.

\section{DeAR Sir,}

\section{HIGH-DOSE NEUROLEPTICS}

The paper by P. Bollini et al (Journal, January 1984, 144, 25-27) on high dose neuroleptics is a sad document of the present situation of Italian psychiatry. Three deaths are of course no chance finding with a procedure which also produced $56 \%$ adverse reactions. The therapy as described should not only be abandoned but has to be condemned. One of the reasons for such practices is the shortage of psychiatric beds in Italy after the law disbanded mental hospitals. 
This unfortunate experiment began in Gorizia (Gorica) mental hospital close to the Yugoslav border (Basaglia, 1968 and Jervis, 1977). The Italian brand of antipsychiatry first maligned psychiatric hospitals as strongholds of social repression and later paradoxically contributed to the worst form of repression, to furor therapeuticus, as described in the paper by P. Bollini $e t$ al.

\section{J. ZALOKAR}

\section{Psihiatrični dispanzer}

Šmpeter pri Gorici, Yugoslavia

\section{References}

Basaglia, F. ed. (1968) L'istituzione Negata. Torino: Einaudi.

Jervis, G. (1977) Manuale Critico di Psichiatria. Milano: Feltrinelli.

\section{MEMORY UNDER THREE DIFFERENT WAVEFORMS OF ECT}

DEAR SiR,

I read with interest the paper by Eric Warren and David Groome which looked at the effect on memory of ECT under three different waveforms (Journal, $1984,144,370-5)$. The electroconvulsive stimuli (ECS) used in this study comprised two of high energy and one of low energy. Their findings confirm earlier research that depression had an adverse effect on certain aspects of memory function. They also conclude that the nature of the ECS had no significant differential effect on memory function. The results, however, do not necessarily support this latter conclusion.

The authors state that the assessment of mood changes in the three groups of patients, reported elsewhere (Robin \& De Tissera, 1984), revealed that the low energy group recovered less quickly than the two high groups and required significantly more ECT. In view of this finding the observations on memory function should only have been made having taken due regard for the differences in the levels of mood disturbance between the three groups. It may well transpire that after allowing for the main effect on memory dysfunction, namely depression, then the secondary effect, that is the nature of the ECS, will be shown to be of relevance.

\section{R. SHAWCROSS}

Mapperley Hospital, Nottingham NG3 6AA

\section{Reference}

Robin, A. \& DE Tissera, S. (1982) A double blind controlled comparison of the therapeutic effects of low and high energy electroconvulsive therapies. British Journal of Psychiatry, 141, 357-66.

\section{COGNITIVE THERAPY - TRAINING THE} PATIENTS

DEAR SIR,

The founders of cognitive therapy are to be congratulated upon their strenuous efforts to establish the efficacy of their treatment.

There is, however, a problem illustrated by such papers as that by Teasdale, Fennell, Hibbert \& Amies (Journal, April, 1984, 144, 400-6). Is it not possible that the therapy directly coaches patients in the responses they should be giving on rating scales?

The therapy is apparently designed to "train patients to identify and correct negative depressive thinking". If patients are trained to correct negative thinking, then this might affect their answers on rating scales where they are asked whether they are "weary of life" or "feel that they have let people down" to mention two items on rating scales used by the writers of the paper. Perhaps they do become trained not to express negative thoughts, but do not become any happier as a result.

11 North Airmont Road,

D. Peter Birkett

\section{Suffern, New York 10901,} USA

SIR,

\section{ROCK AND ROLL DELUSIONS}

Ruedrich et al (1983) reported three patients with delusions involving rock and roll performers. They questioned whether this was an emerging contemporary phenomenon affecting the content of delusions. We have encountered two patients presenting with delusions involving rock performers.

Case 1: An 18 year old, single, white female experienced delusions while at college that Mick Jagger of the Rolling Stones was following her and watching her constantly, causing her to shower fully clothed. She variously believed that his attentions were romantic and benevolent, or malicious and harmful. Premorbid personality was characterized by immature dependency upon her parents and social shyness, offset by unrelenting application to a competitive sport in which she achieved national prowess. There was intense sibling rivalry with a younger sister. During two hospitalizations a diagnosis of schizo-affective disorder with borderline personality was made. Her symptoms improved with anti-psychotic and lithium treatment, but an autistic preoccupation with the words of pop songs persisted.

Case 2: This 32 year old, divorced, white female with a long history of affective and behavioral problems developed delusions while hospitalized. Prior to admission she had impulsively married, then divorced, 